Journal of Agricultural Sciences
(Tarim Bilimleri Dergisi)

\title{
Comparison of Ethylene Sensitivity of Three Tomato Cultivars From Different Tomato Types and Effects of Ethylene on Postharvest Performance
}

\author{
Qasid ALI ${ }^{\mathrm{a}} \mathbb{D}$, Mehmet Seckin KURUBAS ${ }^{\mathrm{a}} \mathbb{D}$, Mustafa ERKAN ${ }^{\mathrm{a} *}$ (D) \\ ${ }^{a}$ Department of Horticulture, Faculty of Agriculture, Akdeniz University 07059 Antalya, TURKEY \\ ARTICLE INFO \\ Research Article \\ Corresponding Author: Mustafa ERKAN, E-mail: erkan@akdeniz.edu.tr \\ Received: 06 April 2020 / Revised: 12 June 2020 / Accepted: 21 July 2020 / Online: 04 December 2021
}

\section{ABSTRACT}

The aim of study was to investigate ethylene sensitivity of different types of tomatoes and the effects of ethylene on their postharvest performance. For that purpose, beefsteak, heirloom and cluster types of tomato fruit were harvested at the breaker maturity stage and divided into two groups one of which was treated with $150 \mu \mathrm{L} \mathrm{L}^{-1}$ ethylene and the other was untreated for comparison. Ethylene treated and untreated fruit were stored at $12{ }^{\circ} \mathrm{C}$ and $90 \pm 5 \%$ relative humidity for 35 days and subsamples removed every 7 days for postharvest quality analysis. After each removal time, fruit were kept at $20^{\circ} \mathrm{C}$ for 3 days in order to determine shelf life performance. Ethylene treatment lead to increase respiration rate, ethylene production, weight loss but decreased fruit firmness in all tested tomato cultivars. Minimum ethylene production and respiration rate occurred in untreated beefsteak tomatoes. At the end of cold storage and shelf life period, the highest $L^{*}$ values and fruit firmness were recorded for control beefsteak tomatoes. The conclusion drawn from this experiment was that the cluster type of tomatoes was more sensitive, while beefsteak type of tomatoes was found to be less sensitive to ethylene treatment as they had the highest and lowest amount of ethylene productions respectively. Untreated beefsteak tomatoes exhibited maximal postharvest quality compared to other treatments after 35 days cold storage and shelf life.

Keywords: Cold storage, Ethylene, Quality, Respiration rate, Shelf life, Tomatoes

(c) Ankara University, Faculty of Agriculture

\section{Introduction}

Internationally tomato is the leading vegetable with an annual production of 177 million tons (MT). China ranked $1^{\text {st }}$ with the production of $61.6 \mathrm{MT}$ whereas Turkey ranked $4^{\text {th }}$ with 12.1 MT production (FAO 2018). Approximately $70 \%$ of tomatoes are freshly consumed while the remaining $30 \%$ of tomatoes are processed for making tomato sauce and a range of tomato-based products including ketchup and juice (Erturk \& Cirka 2015). Tomato, being a climacteric fruit, is highly sensitive to the ripening hormone ethylene. Ethylene induces the ripening of climacteric fruit and is highly effective in modulating biochemical reactions in fruit. Ethylene affects not only biochemical composition but also increases respiration rate and senescence of fruit and vegetables (Prasanna et al. 2007). Additionally, chlorophyll degradation and softening of tomato fruit are caused by ethylene (Akbudak et al. 2007). Effects of ethylene in horticultural produces are mainly dependent upon the cultivar, maturity stage, application dose and temperature (Nagata et al. 1995; Wills et al. 1998; De Wild et al. 2005). Endogenous or exogenous treatment of ethylene is widely used to stimulate and initiate ripening in climacteric fruits. Ethylene is applied to fruit for ripening and improvement in quality of color (Dhall \& Singh 2013). Similar to other fruits and vegetables, maturation causes changes in color, texture, flavor and chemical structure of tomatoes.

The attainment of consumer satisfaction is a challenging task for marketing and therefore breeders are introducing different tomato types and cultivars every year. Respiration rate, ethylene sensitivity, sugars, acids and other biochemical properties vary according to type of tomatoes. In general, tomatoes with higher sugar and acid content have a better taste than those with lower acid and sugar content (Cantwell 2010).

Ethylene production by tomato fruit varies according to type and maturity stage of fruit (Baldwin 2004). Different tomato types show different ripening behavior. Therefore, it is important to determine the response of ethylene in these different types of tomato to benefit commercial growers, breeders, wholesalers and retailers. Therefore, the aim of study was to investigate ethylene sensitivity of different types of tomatoes and the effects of ethylene on their postharvest performance. 


\section{Material and Methods}

Beefsteak (cv. Tybif), heirloom (cv. Yuksel Koy) and cluster (cv. Merkur) types of tomato were harvested at 'breaker stage'. All fruits were obtained from a commercial greenhouse in Antalya, Turkey (36 59'57.3" N 30 51'20.4” E). During the entire vegetation period, uniform irrigation and fertigation management procedures were applied to the tested tomato types. All fruits were harvested on the same day and fruit were immediately transported to the postharvest physiology laboratory at Akdeniz University, Antalya, Turkey. Fruit with any defects i.e. decayed, bruised and non-uniform, were discarded and the remainder were split into two groups. The first group was treated with $150 \mu 1 \mathrm{~L}^{-1}$ of ethylene at $20{ }^{\circ} \mathrm{C}$ in a $20 \mathrm{~m}^{3}$ room for $40 \mathrm{~min}$ and the second group was left untreated (control). Both groups of fruit samples were stored at $12{ }^{\circ} \mathrm{C}$ and $90 \pm 5 \%$ relative humidity for 35 days. Fruit samples for quality analysis were removed from storage at 7 days intervals and kept at $20{ }^{\circ} \mathrm{C}$ and $60 \pm 5 \%$ relative humidity for additional 3 days to simulate shelf life performance.

For ethylene production, 10 fruits from each treatment were enclosed in $5 \mathrm{~L}$ airtight jars for $1 \mathrm{~h}$ at $20{ }^{\circ} \mathrm{C}$, then a $1 \mathrm{~mL}$ gas sample was withdrawn using a gastight syringe and injected into a gas chromatography (GC; Finnigan Trace Ultra, Thermo Electron S.p.A. Strada Rivoltana 20900 Radano, Milan-Italy) equipped with GS-GASPRO, 113-4362 Capillary column, $60 \mathrm{~m} x$ $0.322 \mathrm{~mm}$ calibrated with standard ethylene. The temperature of detector, oven and injection were $170{ }^{\circ} \mathrm{C}, 90{ }^{\circ} \mathrm{C}$ and $100{ }^{\circ} \mathrm{C}$, respectively. Flow rates of carrier gas helium, air and hydrogen were $25 \mathrm{~mL} \mathrm{~min}{ }^{-1}, 350 \mathrm{~mL} \mathrm{~min}^{-1}$ and $35 \mathrm{~mL} \mathrm{~min}^{-1}$, respectively. Ethylene production was reported as $\mu \mathrm{L} \mathrm{C}_{2} \mathrm{H}_{4} \mathrm{~kg}^{-1} \mathrm{~h}^{-1}$ (Dogan et al. 2017).

Respiration rates of fruits were measured as $\mathrm{CO}_{2}$ production. For that purpose, 10 fruits from each treatment were enclosed in $5 \mathrm{~L}$ airtight jars for $1 \mathrm{~h}$ at $20{ }^{\circ} \mathrm{C}$, then a $1 \mathrm{~mL}$ gas sample was taken from the headspace and injected into GC equipped with $80 / 100$ Porapak N, $182.88 \mathrm{~cm}$ x $0.635 \mathrm{~cm}$ column calibrated with standard $\mathrm{CO}_{2}$. The temperatures of detector, oven and injection temperature were $100{ }^{\circ} \mathrm{C}, 65^{\circ} \mathrm{C}$ and $100{ }^{\circ} \mathrm{C}$, respectively. Flow rates of carrier gas helium, air and hydrogen were $10 \mathrm{~mL}$ min ${ }^{-1}$,

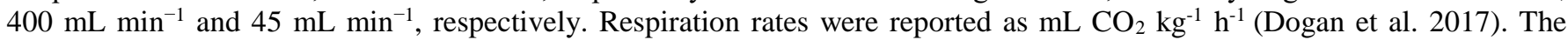
ethylene production and respiration rate analysis were carried out with the same tomatoes for 35 days of storage.

Weight loss was determined by weighing tomatoes at the beginning of the experiment (day 0 ) and at 7 days intervals. Cumulative weight loss was expressed as percentage loss of the initial total weight.

Color changes of tomatoes were recorded with a color meter (CR-400, Minolta, Ramsey, NJ, USA), which directly gave CIE $L^{*}$, hue angle $\left(h^{\circ}\right)$ and chroma $\left(C^{*}\right)$ values. Color measurements were made from 3 different points on the equatorial region of the fruit surface to represent the entire fruit sample. (Mcguire 1992). Total soluble solids (TSS) content was measured with a digital refractometer (Hanna HI 96801) and the TSS was expressed as percent (\%). For titratable acidity (TA), the juice of tomato fruit was obtained using a blender. Determination of TA was done by titrating a juice sample of $2 \mathrm{~mL}$ with $38 \mathrm{~mL}$ of distilled water along with $0.1 \mathrm{~N} \mathrm{NaOH}$ to an end point of 8.1. Each sample was titrated three times and means calculated. The TA was determined as g citric acid $\mathrm{kg}^{-1}$. Fruit firmness of tomato was measured using a penetrometer (FT 011) with 3 mm plunger. Measurements were carried out on three different points of each fruit and firmness was determined in Newton (N). The amount of unmarketable fruit was expressed in percent. The calculation was done according to the following equation (1) used by Jan \& $\operatorname{Rab}(2012)$.

Amount of unmarketable fruit $(\%)=$ number of deteriorated fruit/ total number of fruit x 100 (1)

A completely randomized design with three replications was used for the experiment. Each replication contained ten fruits. Means calculated were subjected to Duncan's multiple range test to determine significant differences. Mean values obtained were analyzed with SAS program.

\section{Results and Discussion}

\subsection{Ethylene production and respiration rate}

\subsubsection{Ethylene production}

Ethylene treated heirloom and beefsteak types of tomato had maximum ethylene production after 21 days storage compared with 28 days for the same types without ethylene treatment. Both control and ethylene treated cluster type tomatoes reached peak ethylene production after 21 days. Maximum ethylene production $\left(3.527 \mu \mathrm{L} \mathrm{C}_{2} \mathrm{H}_{4} \mathrm{~kg}^{-1} \mathrm{~h}^{-1}\right)$ occurred in the ethylene treated cluster type with the least ethylene $\left(1.225 \mu \mathrm{L} \mathrm{C}_{2} \mathrm{H}_{4} \mathrm{~kg}^{-1} \mathrm{~h}^{-1}\right)$ in control beefsteak tomatoes (Figure 1). 


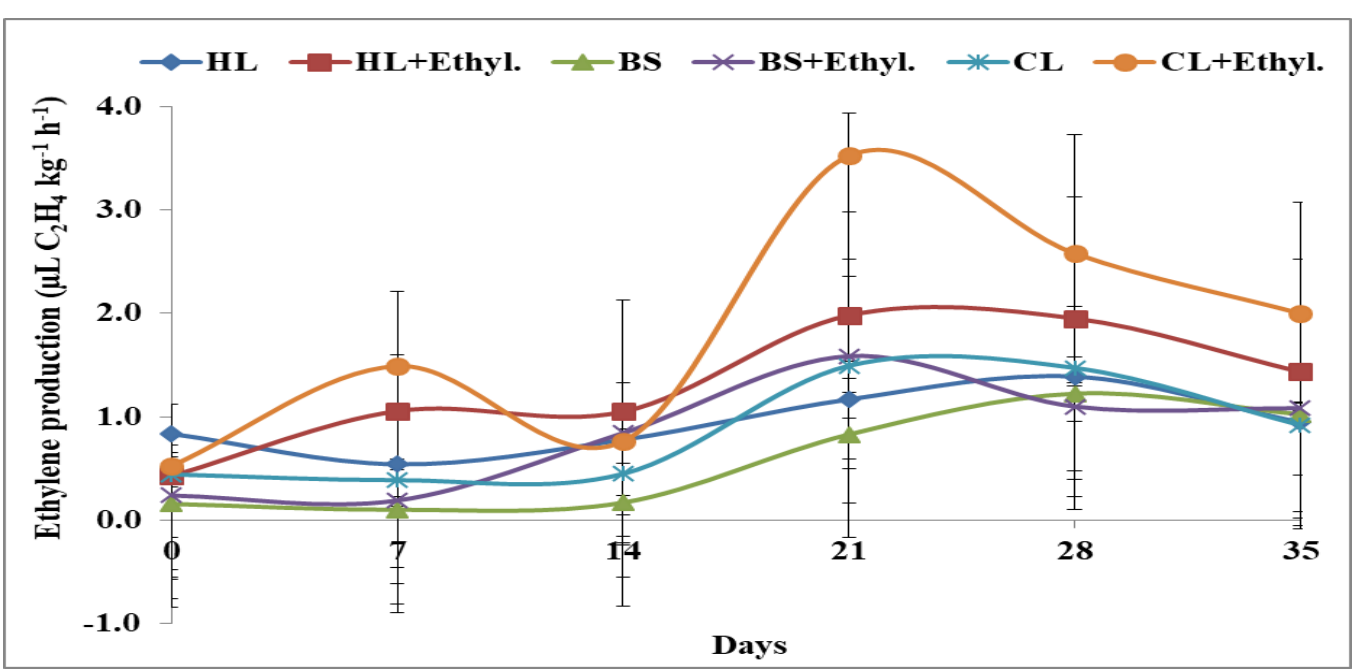

Figure 1- Effect of $150 \mu \mathrm{L} \mathrm{L}-1$ ethylene treatment on ethylene production in different types of tomatoes at $12{ }^{\circ} \mathrm{C}$. Vertical lines represent standard deviations of the means $(n=3)$. ${ }^{\dagger} B S=$ Beefsteak, $B S+E t h y l . ~=~ B e e f s t e a k+E t h y l e n e, ~ H L=H e i r l o o m$,

HL+Ethyl. $=$ Heirloom + Ethylene, $\mathrm{CL}=$ Cluster, $\mathrm{CL}+$ Ethyl. $=$ Cluster+Ethylene

Extension in storage resulted in increase of ethylene in this study with higher ethylene production in ethylene treated fruit which agreed with the result of Chomchalow et al. (2002) who reported an increase in ethylene production with advanced ripening in tomatoes treated by ethylene. Maximum ethylene production was obtained in ethylene treated fruit during our study as compared to untreated fruit which agreed to the outcome of Dong et al. (2001) who reported that ethylene treated 'Flavortop' nectarines had higher ethylene production.

\subsubsection{Respiration rate}

Control heirloom type had a climacteric maximum after 35 days of storage compared with 14 days for ethylene treated heirloom tomatoes. Control beefsteak type reached a climacteric maximum in 14 days while ethylene treated beefsteak type of tomatoes had climacteric maximum on $28^{\text {th }}$ day of storage. Control cluster type of tomatoes reached climacteric maximum on $35^{\text {th }}$ day with ethylene treated cluster type had climacteric maximum on day 0 . Maximum respiration rate of $2.171 \mathrm{~mL} \mathrm{CO}_{2} \mathrm{~kg}^{-1} \mathrm{~h}^{-1}$ occurred in control cluster type after 35 days storage with minimum respiration rate of $1.072 \mathrm{~mL} \mathrm{CO}_{2} \mathrm{~kg}^{-1} \mathrm{~h}^{-1} \mathrm{occurred}$ in control beefsteak type of tomatoes 14 days after storage (Figure 2).

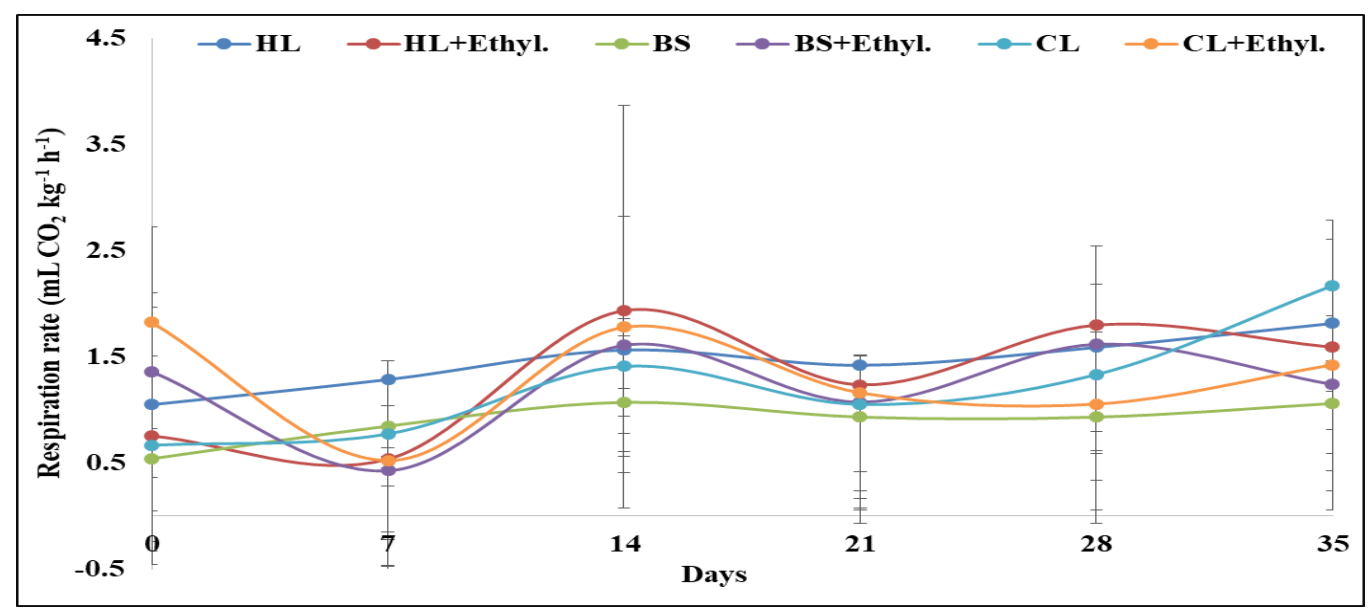

Figure 2- Effect of $150 \mu \mathrm{L} \mathrm{L}^{-1}$ ethylene treatment on respiration rate in different types of tomatoes at $12{ }^{\circ} \mathrm{C}$. Vertical lines represent standard deviations of the means $(n=3)$. $B S=$ Beefsteak, $B S+E t h y l .=$ Beefsteak+Ethylene, $H L=H e i r l o o m$, HL+Ethyl.= Heirloom+Ethylene, $\mathrm{CL}=$ Cluster, $\mathrm{CL}+\mathrm{Ethyl} .=$ Cluster+Ethylene

Rise in respiration rate of tomatoes was observed by Karacali (1990) as noticed in our study. Boe \& Salunkhe (1967) in tomatoes and Elmi et al. (2017) in strawberries reported that the ethylene treatment increased the rate of $\mathrm{CO}_{2}$ production. However, their outcome contradicted with cluster type tomatoes where control treatment had higher $\mathrm{CO}_{2}$ production than ethylene treated tomatoes. Respiration rate of tomato fruit is one of the vital indicators of senescence climacteric fruit (Maharaj et al. 1999). Similarly, according to Gonzalez-Aguilar et al. (2010) respiration rate and ethylene productions are main components to determine decay incidence of fruit and vegetables. 


\subsection{Weight loss}

Ethylene treatment in all tomato types resulted in higher amount of weight loss in the fruit. Weight loss of tomatoes increased both in cold storage and shelf life during storage period. After cold storage, greatest weight loss (5.90\%) was from ethylene treated cluster fruit whereas lowest weight loss (2.37\%) was in control beefsteak tomatoes (Table 1). At the end of 35+3 days storage and shelf life period, maximum weight loss $(8.48 \%)$ occurred in ethylene treated cluster tomatoes whereas minimum weight loss $(3.84 \%)$ occurred in control beefsteak tomatoes (Table 2). The interactions between storage duration and treatments were significant in both cold storage and shelf life conditions at $\mathrm{P} \leq 0.05$.

Table 1- Effect of ethylene on weight loss, color $\left(L^{*}, C^{*}, h^{\circ}\right)$, total soluble solids, titratable acidity, fruit firmness and amount of unmarketable fruit of different types of tomatoes during storage at $12{ }^{\circ} \mathrm{C}$

\begin{tabular}{|c|c|c|c|c|c|c|c|}
\hline \multirow{2}{*}{ Parameters } & \multirow{2}{*}{ Treatments } & \multicolumn{6}{|c|}{ Storage duration (Days) } \\
\hline & & $\mathbf{0}$ & 7 & 14 & 21 & 28 & 35 \\
\hline \multirow{7}{*}{$\begin{array}{l}\text { Weight loss } \\
(\%)\end{array}$} & $\mathbf{B S}^{\dagger}$ & - & $0.68 \mathrm{jk} *$ & $0.87 \mathrm{jk}$ & $1.09 \mathrm{jk}$ & $1.60 \mathrm{fk}$ & $2.37 \mathrm{df}$ \\
\hline & BS+Ethyl. & - & $0.53 \mathrm{k}$ & $0.89 \mathrm{jk}$ & $1.16 \mathrm{hk}$ & $2.21 \mathrm{dh}$ & $3.25 \mathrm{bd}$ \\
\hline & HL & - & $0.49 \mathrm{k}$ & $0.80 \mathrm{jk}$ & $1.00 \mathrm{jk}$ & $1.60 \mathrm{fk}$ & $2.40 \mathrm{df}$ \\
\hline & HL+Ethyl. & - & $0.65 \mathrm{jk}$ & $0.94 \mathrm{jk}$ & $1.20 \mathrm{gk}$ & $2.10 \mathrm{ei}$ & $2.85 \mathrm{ce}$ \\
\hline & CL & - & $0.64 \mathrm{jk}$ & $1.72 \mathrm{fj}$ & $2.08 \mathrm{ei}$ & $3.68 \mathrm{bc}$ & $5.11 \mathrm{a}$ \\
\hline & CL+Ethyl. & - & $0.63 \mathrm{jk}$ & $1.20 \mathrm{gk}$ & $2.27 \mathrm{dg}$ & $4.13 b$ & $5.90 \mathrm{a}$ \\
\hline & & LSD & Dur.: 0.41 & Our. $\times$ Trt & 37 Trt.: 0.37 & & \\
\hline \multirow[t]{7}{*}{ Brightness $\left(L^{*}\right)$} & BS & $54.69 a$ & $54.36 \mathrm{ab}$ & $54.03 \mathrm{ab}$ & $52.85 \mathrm{ae}$ & $53.33 \mathrm{ad}$ & $50.18 \mathrm{ah}$ \\
\hline & BS+Ethyl. & $53.67 \mathrm{ad}$ & $53.84 \mathrm{ac}$ & $53.37 \mathrm{ad}$ & 49.89bi & 48.46ei & $46.23 \mathrm{hl}$ \\
\hline & HL & 52.30af & $50.94 \mathrm{ag}$ & $49.13 \mathrm{di}$ & $46.61 \mathrm{gk}$ & $45.98 \mathrm{hl}$ & $43.57 \mathrm{jm}$ \\
\hline & HL+Ethyl. & $49.37 \mathrm{ci}$ & $48.64 \mathrm{ei}$ & $46.86 \mathrm{gj}$ & $43.71 \mathrm{jl}$ & $42.29 \mathrm{kn}$ & $40.33 \mathrm{mn}$ \\
\hline & CL & $50.08 \mathrm{bi}$ & $49.81 \mathrm{bi}$ & $46.10 \mathrm{gk}$ & $42.02 \ln$ & $41.00 \mathrm{mn}$ & $40.08 \mathrm{mn}$ \\
\hline & CL+Ethyl. & $50.57 \mathrm{ah}$ & $48.23 \mathrm{fi}$ & $45.64 \mathrm{il}$ & 43.34jm & $40.06 \mathrm{mn}$ & $37.96 n$ \\
\hline & & LSD & Dur.: 1.55 & Dur. $\times$ Trt & 31 Trt.: 1.55 & & \\
\hline \multirow{7}{*}{ Chroma $\left(C^{*}\right)$} & BS & $26.81 \mathrm{kl}$ & $26.68 \mathrm{kl}$ & $29.87 \mathrm{hk}$ & $36.05 \mathrm{ae}$ & $37.83 \mathrm{ad}$ & $39.20 \mathrm{a}$ \\
\hline & BS+Ethyl. & $26.55 \mathrm{kl}$ & $27.13 \mathrm{kl}$ & $27.69 \mathrm{kl}$ & $32.43 \mathrm{fi}$ & $35.36 \mathrm{bg}$ & $38.39 \mathrm{a}$ \\
\hline & HL & $27.50 \mathrm{kl}$ & $28.26 \mathrm{jl}$ & $29.33 \mathrm{ik}$ & $33.81 \mathrm{eg}$ & $34.61 \mathrm{dg}$ & $36.93 \mathrm{ae}$ \\
\hline & HL+Ethyl. & $26.62 \mathrm{kl}$ & 28.36jl & $28.45 \mathrm{j} 1$ & $33.84 \mathrm{eg}$ & $34.67 \mathrm{cg}$ & 35.86af \\
\hline & CL & 25.541 & $27.46 \mathrm{kl}$ & $31.92 \mathrm{gj}$ & $35.33 \mathrm{bg}$ & $38.32 \mathrm{ad}$ & $38.48 \mathrm{ab}$ \\
\hline & CL+Ethyl. & $26.18 \mathrm{kl}$ & $29.61 \mathrm{ik}$ & $31.86 \mathrm{gj}$ & $37.06 \mathrm{ae}$ & 35.91af & $33.56 \mathrm{eh}$ \\
\hline & & LS & t. Dur.: 1.5 & Our. $\times$ Trt & 9 Trt.: 1.53 & & \\
\hline \multirow{7}{*}{$\begin{array}{l}\text { Hue angle } \\
\left(h^{\circ}\right)\end{array}$} & BS & $115.61 \mathrm{a}$ & $111.11 \mathrm{a}$ & $96.77 \mathrm{be}$ & 84.02eh & $67.35 \mathrm{hn}$ & $60.64 \mathrm{jq}$ \\
\hline & BS+Ethyl. & $115.28 \mathrm{a}$ & $101.44 \mathrm{ad}$ & $84.24 \mathrm{eh}$ & $74.64 \mathrm{gj}$ & $67.74 \mathrm{hm}$ & $65.48 \mathrm{io}$ \\
\hline & HL & $113.56 \mathrm{ab}$ & $104.70 \mathrm{ac}$ & $87.19 \mathrm{dg}$ & $75.28 \mathrm{gj}$ & 63.31ip & $53.561 \mathrm{q}$ \\
\hline & HL+Ethyl. & $112.31 \mathrm{ab}$ & $92.51 \mathrm{cf}$ & $70.73 \mathrm{gl}$ & $57.98 \mathrm{jq}$ & $50.42 \mathrm{mq}$ & $48.17 \mathrm{oq}$ \\
\hline & CL & $78.95 \mathrm{fi}$ & $72.44 \mathrm{gk}$ & $56.81 \mathrm{kq}$ & $49.73 \mathrm{nq}$ & $47.61 \mathrm{oq}$ & $45.27 \mathrm{q}$ \\
\hline & CL+Ethyl. & $79.11 \mathrm{fi}$ & 63.98ip & $52.83 \mathrm{mq}$ & $49.58 \mathrm{nq}$ & $46.32 \mathrm{pq}$ & $45.09 q$ \\
\hline & & LSD & Dur.: 6.07 & Our. $\times$ Trt & 1 Trt.: 6.07 & & \\
\hline \multirow{7}{*}{$\begin{array}{l}\text { Total soluble } \\
\text { solids (TSS) } \\
(\%)\end{array}$} & BS & $4.10 \mathrm{ae}$ & 4.10ae & $3.90 \mathrm{be}$ & $3.97 \mathrm{ae}$ & $4.10 \mathrm{ae}$ & $3.87 \mathrm{ce}$ \\
\hline & BS+Ethyl. & $4.00 \mathrm{ae}$ & $3.90 \mathrm{be}$ & $3.87 \mathrm{ce}$ & $3.93 \mathrm{ae}$ & $4.00 \mathrm{ae}$ & $3.87 \mathrm{ce}$ \\
\hline & HL & $4.23 \mathrm{ab}$ & $3.97 \mathrm{ae}$ & $4.13 \mathrm{ad}$ & $4.03 \mathrm{ae}$ & $4.00 \mathrm{ae}$ & $3.83 \mathrm{de}$ \\
\hline & HL+Ethyl. & 4.13ad & $4.27 \mathrm{a}$ & $3.93 \mathrm{ae}$ & $3.77 \mathrm{e}$ & 3.90be & $4.03 \mathrm{ae}$ \\
\hline & CL & $3.93 \mathrm{ae}$ & $3.97 \mathrm{ae}$ & $4.03 \mathrm{ae}$ & $4.07 \mathrm{ae}$ & $4.10 \mathrm{ae}$ & $4.20 \mathrm{ac}$ \\
\hline & CL+Ethyl. & $3.90 \mathrm{be}$ & $3.97 \mathrm{ae}$ & $3.97 \mathrm{ae}$ & $4.07 \mathrm{ae}$ & 4.13ad & $4.20 \mathrm{ac}$ \\
\hline & & $\mathrm{LSD}_{\mathbf{s}}$ & Dur.: 0.11 & . Trt.: 0 & Trt.: 0.11 & & \\
\hline \multirow{7}{*}{$\begin{array}{l}\text { Titratable } \\
\text { acidity } \\
(\mathrm{g} \text { citric acid kg-1) }\end{array}$} & BS & $5.50 \mathrm{~cd}$ & $4.13 \mathrm{fj}$ & $3.50 \mathrm{ik}$ & $3.30 \mathrm{jk}$ & $3.20 \mathrm{jk}$ & $3.17 \mathrm{jk}$ \\
\hline & BS+Ethyl. & $3.87 \mathrm{fk}$ & $3.37 \mathrm{ik}$ & $3.30 \mathrm{jk}$ & $3.27 \mathrm{jk}$ & $3.17 \mathrm{jk}$ & $3.03 \mathrm{jk}$ \\
\hline & HL & $8.13 \mathrm{a}$ & $6.93 b$ & $4.80 \mathrm{cf}$ & $4.73 \mathrm{dg}$ & 4.30ei & $3.53 \mathrm{ik}$ \\
\hline & HL+Ethyl. & $7.93 \mathrm{a}$ & $5.13 \mathrm{ce}$ & 5.10ce & $3.97 \mathrm{fk}$ & $3.80 \mathrm{gk}$ & $3.27 \mathrm{jk}$ \\
\hline & CL & $5.70 \mathrm{c}$ & 5.17ce & 4.33ei & $3.80 \mathrm{gk}$ & $3.80 \mathrm{gk}$ & $3.63 \mathrm{hk}$ \\
\hline & CL+Ethyl. & $4.73 \mathrm{dg}$ & $4.57 \mathrm{dh}$ & $3.80 \mathrm{gk}$ & $3.47 \mathrm{ik}$ & $3.40 \mathrm{ik}$ & $3.40 \mathrm{ik}$ \\
\hline & LSD $_{5 \%}$ : St. I & t. Dur. $\times 1$ & 8102 Trt.: & & & & \\
\hline \multirow{7}{*}{ Fruit firmness (N) } & BS & $13.20 \mathrm{a}$ & $12.37 \mathrm{ae}$ & $11.54 \mathrm{bf}$ & $10.54 \mathrm{fh}$ & $7.45 \mathrm{jl}$ & $6.83 \mathrm{~km}$ \\
\hline & BS+Ethyl. & $12.47 \mathrm{ad}$ & $11.89 \mathrm{bf}$ & $11.42 \mathrm{bg}$ & $9.92 \mathrm{gi}$ & $7.50 \mathrm{jl}$ & $6.111 n$ \\
\hline & HL & $12.63 \mathrm{ac}$ & $11.37 \mathrm{bg}$ & $8.63 \mathrm{ij}$ & $6.87 \mathrm{~km}$ & $5.38 \mathrm{mo}$ & $4.43 \mathrm{op}$ \\
\hline & HL+Ethyl. & $12.36 \mathrm{ae}$ & $10.89 \mathrm{eg}$ & 9.30hi & $6.83 \mathrm{~km}$ & $4.85 n p$ & $3.52 \mathrm{p}$ \\
\hline & CL & $12.66 \mathrm{ab}$ & $10.86 \mathrm{eg}$ & $10.61 \mathrm{fh}$ & $7.58 \mathrm{j} 1$ & $6.72 \mathrm{~km}$ & 4.16op \\
\hline & CL+Ethyl. & $12.62 \mathrm{ac}$ & $11.07 \mathrm{cg}$ & $10.98 \mathrm{dg}$ & $7.76 \mathrm{jk}$ & 4.51op & $3.82 \mathrm{p}$ \\
\hline & LSD $_{\mathbf{5} \%}: 0.54$ & Dur. $\times$ T & 3324 Trt.: 0 & & & & \\
\hline \multirow{6}{*}{$\begin{array}{l}\text { Amount of } \\
\text { unmarketable } \\
\text { fruit }(\%)\end{array}$} & BS & $\mathrm{Oh}$ & $\mathrm{Oh}$ & $\mathrm{Oh}$ & $8.06 \mathrm{gh}$ & $19.25 \mathrm{df}$ & $30.40 b c$ \\
\hline & BS+Ethyl. & Oh & Oh & Oh & $13.94 \mathrm{fg}$ & 23.40ce & $34.78 b$ \\
\hline & HL & $\mathrm{Oh}$ & Oh & Oh & $13.40 \mathrm{fg}$ & $20.78 \mathrm{df}$ & $30.40 \mathrm{bc}$ \\
\hline & HL+Ethyl. & Oh & Oh & $\mathrm{Oh}$ & $4.84 \mathrm{~h}$ & $15.01 \mathrm{fg}$ & $51.96 \mathrm{a}$ \\
\hline & CL & Oh & $\mathrm{Oh}$ & $\mathrm{Oh}$ & $4.73 \mathrm{~h}$ & $15.98 \mathrm{ef}$ & $25.50 \mathrm{~cd}$ \\
\hline & CL+Ethyl. & $0 \mathrm{~h}$ & $\mathrm{Oh}$ & $1.23 \mathrm{~h}$ & $3.09 \mathrm{~h}$ & $15.51 \mathrm{fg}$ & $45.48 \mathrm{a}$ \\
\hline
\end{tabular}

*: Means with different letters are statistically significant at $\mathrm{P} \leq 0.05$ according to Duncan's multiple range test; 'BS: Beefsteak; BS+Ethyl.: Beefsteak+Ethylene; HL: Heirloom; HL+Ethyl.: Heirloom+Ethylene; CL: Cluster; CL+Ethyl.: Cluster+Ethylene; LSD: Least significant difference; St. Dur.: Storage duration; St. Dur. $\times$ Trt.: Storage duration $\times$ Treatments; Trt: Treatments 
Table 2- Effect of ethylene on weight loss, color $\left(L^{*}, C^{*}, h^{\circ}\right)$ and total soluble solids contents of different types of tomatoes under shelf life at $20^{\circ} \mathrm{C}$

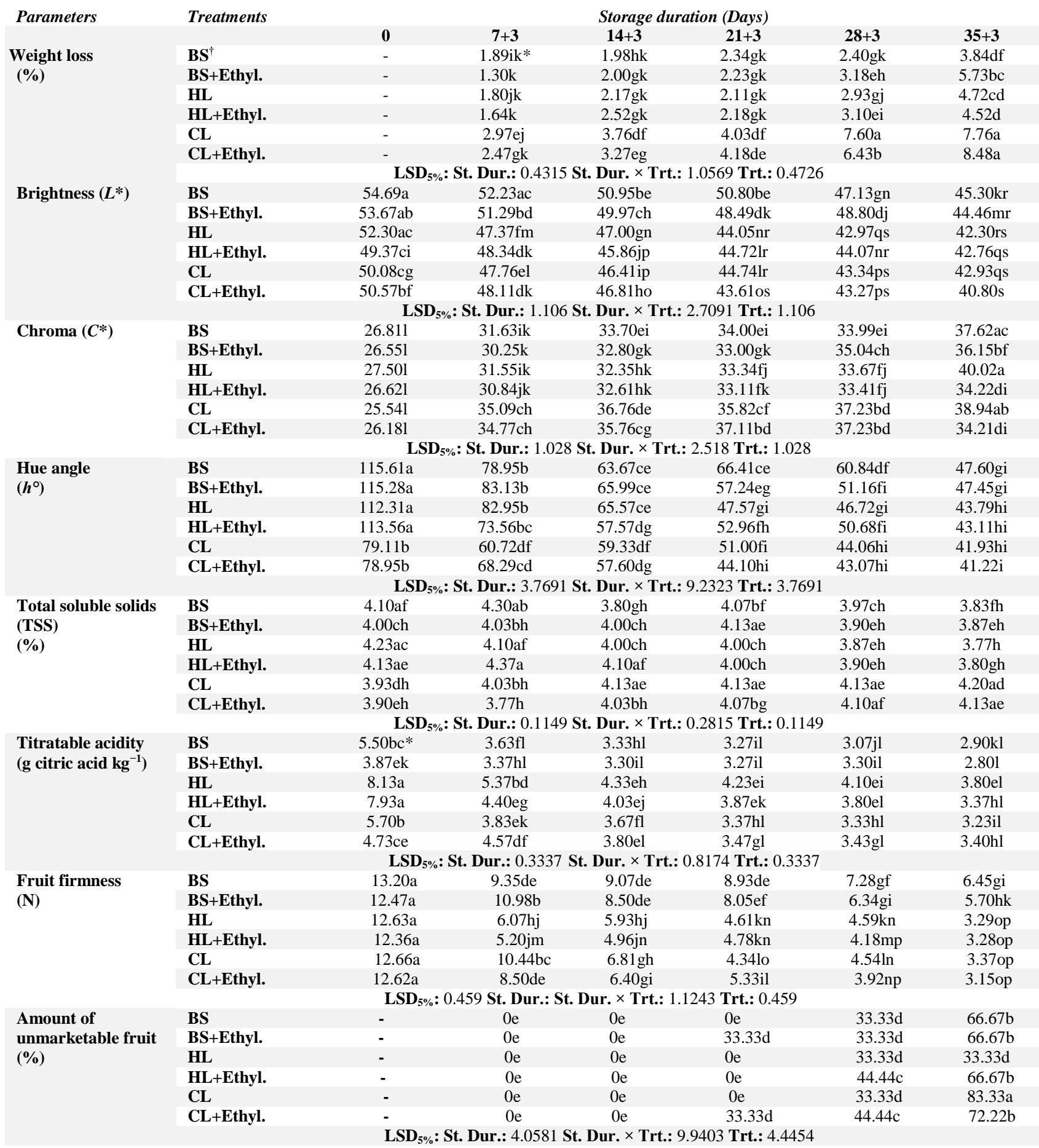

*: Means with different letters are statistically significant at $\mathrm{P} \leq 0.05$ according to Duncan's multiple range test; ${ }^{\dagger} \mathrm{BS}$ : Beefsteak; BS+Ethyl.: Beefsteak+Ethylene; HL: Heirloom; HL+Ethyl.: Heirloom+Ethylene; CL: Cluster; CL+Ethyl.: Cluster+Ethylene, LSD: Least significant difference; St. Dur.: Storage duration; St. Dur. $\times$ Trt.: Storage duration $\times$ Treatments; Trt: Treatments.

Increases in weight losses with tomato ripening was reported by Sammi \& Masud (2007) which was similar outcome obtained in this study. In this experiment ethylene treated fruit had higher weight losses as compared to control which agreed with the outcome of Dhall \& Singh (2013) who expressed that ethylene treated tomatoes had more weight loss than control treatment. They mentioned that this increases in weight loss may be due to the rise in respiration rate during ripening.

\subsection{Fruit color $\left(L^{*}, C^{*}, h^{\circ}\right)$}

The $L^{*}$ values tended to decline with time in cold storage and shelf life. In general, ethylene treatment in tomato fruit resulted in lower $L^{*}$ values than the untreated ones. The interactions between storage duration and treatments were significant under cold 
storage and shelf life at $\mathrm{P} \leq 0.05$. After cold storage, the highest $L^{*}$ value (50.18) was in control beefsteak whereas the lowest $L^{*}$ value (37.96) was in ethylene treated cluster tomatoes after 35 days storage (Table 1). At the end of shelf life, maximum $L^{*}$ value (45.30) was in untreated beefsteak tomatoes and minimum (40.80) $L^{*}$ value was in ethylene treated cluster tomatoes treated after $35+3$ days storage (Table 2 ).

Decrease in $L^{*}$ values with storage extension of tomatoes were reported by Fagundes et al. (2015). According to these researchers the decrease in $L^{*}$ values may be due to increase in the red color of tomatoes during storage. Camelo \& Gomez (2004) mentioned that as the red pigmentation of tomatoes started to synthesize the $L^{*}$ values showed decrease and had attained the dark red color.

Interactions between storage duration and treatments were statistically significant at $\mathrm{P} \leq 0.05$. After cold storage, the highest $C^{*}$ value (39.20) were in control beefsteak tomatoes and ethylene treated cluster tomatoes had the lowest $C^{*}$ value (33.56) (Table 1). After shelf life, maximum $C^{*}$ value (40.02) was in untreated heirloom tomatoes while minimum $C^{*}$ value $(34.21)$ was in ethylene treated cluster tomatoes (Table 2).

In the current study, different types of tomato exhibit increase in $C^{*}$ values which was supported by the findings of DavilaAvina et al. (2011) who reported rise in $C^{*}$ value throughout storage of tomatoes. Camelo \& Gomez (2004) revealed that $C^{*}$ had not been a good indicator to signify the ripening of tomatoes. However, it can be used as a suitable parameter for acceptance of consumers regarding tomatoes that are fully ripe.

In general, ethylene treated tomatoes had lower $h^{\circ}$ values than untreated ones and prolonging storage duration decreased $h^{\circ}$ values. After cold storage maximum $h^{\circ}$ value $\left(65.48^{\circ}\right)$ occurred in ethylene treated beefsteak type with minimum $h^{\circ}$ value $\left(45.09^{\circ}\right)$ in ethylene treated cluster tomatoes (Tables 1). After shelf life, highest $h^{\circ}$ value $\left(47.60^{\circ}\right)$ occurred in control beefsteak type, while the lowest $h^{\circ}$ value $\left(41.22^{\circ}\right)$ was in ethylene treated cluster tomatoes (Table 2).

Decreases in $h^{\circ}$ values of tomatoes with extending storage duration was found by Chomchalow et al. (2002) as obtained from this study. Cantwell (2010) reported that the lower the $h^{\circ}$ values the redder will be the fruit. Tomatoes attained red color with increase in storage and cluster type tomatoes was redder as compared to beefsteak and heirloom types in our study.

\subsection{Total soluble solids (TSS)}

TSS content in beefsteak and heirloom types decreased during storage but increased in cluster type fruit. After cold storage, highest TSS content (4.20\%) occurred in both control and ethylene treated cluster type with lowest TSS content (3.83\%) in control heirloom fruit (Table 1). At the end of shelf life period, maximum TSS content (4.20\%) was in control cluster fruit while minimum TSS content (3.77\%) was in control heirloom type tomatoes (Table 2).

Davila-Avina et al. (2011) expressed that tomato fruit harvested at pink maturity stage showed a decrease in TSS content during storage that agreed with our results regarding beefsteak and heirloom type of tomatoes however it contradicted with cluster type of tomatoes which exhibited increase in TSS content. Similar findings regarding cluster type of tomatoes were reported by Dhall \& Singh (2013). They stated that this rise could be because of water loss, hydrolyzation of starch and other polysaccharides to soluble forms of sugar. However, their results contrasted with our findings for heirloom and beefsteak type of tomatoes which had a slight rise in TSS content at first and then decreased by the end of both cold storage and shelf life period. Increase in TSS content of cluster type of tomatoes with extending storage duration was reported by Mohammed et al. (1999).

\subsection{Titratable acidity $(T A)$}

The extension in storage duration considerably decreased the TA in cold storage and shelf life conditions. Ethylene treated tomatoes had lower TA than untreated ones. At the end of cold storage, the highest TA ( $3.63 \mathrm{~g}$ citric acid kg ${ }^{-1}$ ) was exhibited by control cluster type whereas the lowest TA $\left(3.03 \mathrm{~g}\right.$ citric acid $\left.\mathrm{kg}^{-1}\right)$ was recorded in ethylene treated beefsteak type of tomatoes (Table 1). At the end of shelf life period, the maximum TA (3.80 g citric acid $\left.\mathrm{kg}^{-1}\right)$ was found in control heirloom type while

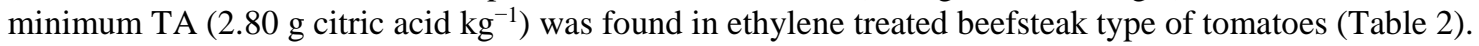

Decrease in TA with extension in storage duration was exhibited by different types of tomato in this study which agreed with the findings of Tigist et al. (2013) who stated that TA decreased with extension in storage. The reasons for decline in TA during our experiment can be due to the loss of citric and malic acid during ripening as reported by Sammi \& Masud (2007) or it may be because of triggering of ethylene production that influence the organic acids and total soluble solids in tomatoes and other climacteric fruit as mentioned by Guilen et al. (2007).

\subsection{Fruit firmness}

Different types of tomatoes had a decline in fruit firmness with prolonging storage period. In general ethylene treated tomatoes had lower fruit firmness than non-treated tomatoes. Significant interaction between the storage duration and treatments existed 
at $\mathrm{P} \leq 0.05$. At the end of cold storage, the untreated beefsteak type of tomatoes had maximum fruit firmness (6.83 $\mathrm{N})$ while minimum fruit firmness $(3.52 \mathrm{~N})$ was determined in ethylene treated heirloom type of tomatoes (Table 1$)$. At the end of shelf life period, the highest fruit firmness $(6.45 \mathrm{~N})$ was exhibited by control beefsteak type whereas lowest fruit firmness $(3.15 \mathrm{~N})$ was displayed by ethylene treated cluster type of tomatoes (Table 2).

Dhall \& Singh (2013) revealed that ethylene treated tomatoes had less fruit firmness than control fruit as obtained in our study. Nyalala \& Wainright (1998) expressed that storage of tomatoes at high temperatures result in lower fruit firmness than those stored at low temperatures which can be because of increased activity of polygalacturonase at $20{ }^{\circ} \mathrm{C}$ as mentioned by Kapotis et al. (2004). These findings agreed with more decrease in fruit firmness of tomatoes in the shelf life period than cold storage in this study.

\subsection{Amount of unmarketable fruit}

Quantity of unmarketable fruit increased with time in storage and shelf life. Ethylene treatment resulted in more unmarketable fruit than in controls apart from cluster tomatoes after shelf life. Significant interaction $(\mathrm{P} \leq 0.05)$ between storage duration and treatments occurred. At the end of cold storage, maximum 51.96\% of unmarketable fruit occurred in ethylene treated heirloom tomatoes whereas minimum unmarketable fruit (25.50\%) was in control cluster type of tomatoes (Table 1). At the end of shelf life, the most unmarketable fruit $(83.33 \%)$ was in control cluster fruit with the least (33.33\%) was in control heirloom fruit (Table 2).

Our results regarding higher unmarketable fruit in ethylene treated tomatoes during cold storage was supported by Geeson et al. (1986). They reported that ethylene treatment had enhanced decay development in tomato however this outcome contradicted with results of shelf life where control cluster type of tomatoes had highest unmarketable fruit. According to Cheng \& Shewfelt (1988) storage of tomatoes at $4{ }^{\circ} \mathrm{C}$ for 15 days and then ripening at ambient temperature increased ethylene production and vulnerability to decay which support our findings of higher amount of unmarketable fruit during shelf life as compared to cold storage. According to Gonzalez-Aguilar et al. (2010) $\mathrm{CO}_{2}$ and ethylene productions are vital components which determine the level of decay development in fruit and vegetables.

\section{Conclusions}

The conclusion drawn from the results obtained is that cluster type tomatoes were recorded to be more sensitive to ethylene treatment than beefsteak and heirloom types as they had produced the highest ethylene during cold storage. Beefsteak type tomatoes retained better postharvest quality than heirloom and cluster types of tomatoes at the end of cold storage and shelf life. Ethylene treatment resulted in higher ethylene production, weight loss with lower fruit firmness. At the end of cold storage, minimum ethylene production, respiration rate and maximum $L^{*}, C^{*}$, fruit firmness were found in control beefsteak type. Ethylene application in beefsteak type resulted in maximum $h^{\circ}$ value. The highest titratable acidity and lowest amount of unmarketable fruit were noticed in control cluster type of tomatoes. At the end of shelf-life period; minimum weight loss and maximum $L^{*}, h^{\circ}$, fruit firmness was noted in control beefsteak type. The lowest amount of unmarketable fruit and highest titratable acidity was obtained in control heirloom type. The highest total soluble solids contents were observed in control cluster type of tomatoes. Variations among the different types of tomato existed which can be taken into consideration prior to storage by the commercial growers, storage operators and wholesalers.

\section{Acknowledgements}

The financial support for this study was provided by Scientific Research Projects Coordination Unit of Akdeniz University (Project No: FYL-2017-2200). The authors thank Prof. Errol W. Hewett for critical review of the manuscript.

\section{References}

Akbudak B, Akbudak N, Seniz V \& Eris A (2007). Sequential treatments of hot water and modified atmosphere packaging in cherry tomatoes. Journal of Food Quality 30(6): 896-910 https://doi.org/10.1111/j.1745-4557.2007.00168.x

Baldwin E A (2004). Ethylene and postharvest commodities. HortScience 39(7): 1538-1540

Boe A A \& Salunkhe D K (1967). Ripening tomatoes: Ethylene, oxygen, and light treatments. Economic Botany 21(4): $312-319$ https://doi.org/10.1007/BF02863156

Camelo A F L \& Gomez P A (2004). Comparison of color indexes for tomato ripening. Horticultura Brasileira 22(3): 534-537 https://doi.org/10.1590/S0102-05362004000300006

Cantwell M (2010). Optimum Procedures for Ripening Tomatoes. In: Fruit Ripening and Ethylene Management, J.T. Thompson and C. Crisosto (eds.), UC Postharvest Horticulture Series 9: 106-116

Chomchalow S, El Assi N M, Sargent S A \& Brecht J K (2002). Fruit maturity and timing of ethylene treatment affect storage performance of green tomatoes at chilling and nonchilling temperatures. HortTechnology 12(1): 104-114 https://doi.org/10.21273/HORTTECH.12.1.104

Cheng T S \& Shewfelt R L (1988). Effect of chilling exposure of tomatoes during subsequent ripening. Journal of Food Science 53(4): 11601162 https://doi.org/10.1111/j.1365-2621.1988.tb13552.x 
Davila-Avina J E J, Villa-Rodríguez J, Cruz-Valenzuela R, Rodríguez-Armenta M, Espino-Díaz M, Ayala-Zavala J F, Olivas-Orozco G I, Heredia B \& González- Aguilar G (2011). Effect of edible coatings, storage time and maturity stage on overall quality of tomato fruit. American Journal of Agricultural and Biological Sciences 6(1): 162-171

De Wild H P J, Balk P A, Fernandes E C A \& Peppelenbos H W (2005). The action site of carbon dioxide in relation to inhibition of ethylene production in tomato fruit. Postharvest Biology and Technology 36(3):272-280 https://doi.org/10.1016/j.postharvbio.2005.02.004

Dogan A, Kurubas M S \& Erkan M (2017). The effects of different doses of 1-Methylcyclopropene (1-MCP) on postharvest quality of "Hass" avocado fruit. Mediterranean Agricultural Sciences 30(2): 71-78 (In Turkish)

Dhall R K \& Singh P (2013). Effect of ethephon and ethylene gas on ripening and quality of tomato (Solanum lycopersicum L.) during cold storage. Journal of Nutrition and Food Sciences 3(6): 1-7 10.4172/2155-9600.1000244

Dong L, Zhou H W, Sonego L, Lers A \& Lurie S (2001). Ethylene involvement in the cold storage disorder of 'Flavortop' nectarine. Postharvest Biology and Technology 23(2): 105-115 https://doi.org/10.1016/S0925-5214(01)00106-5

Elmi F, Pradas I, Tosetti R, Cools K \& Terry LA (2017). Effect of ethylene on postharvest strawberry fruit tissue biochemistry. Acta Horticulturae 1156: 667-672 10.17660/ActaHortic.2017.1156.97

Erturk YE \& Cirka M (2015). Production and marketing of tomatoes in Turkey and North East Anadolu region. Yuzuncu Yll University Journal of Agricultural Sciences 25(1): 84-97 (In Turkish)

Fagundes C, Moraes K, Perez-Gago MB, Palou L, Maraschin M \& Monteiro AR (2015). Effect of active modified atmosphere and cold storage on the postharvest quality of cherry tomatoes. Postharvest Biology and Technology 109:73-81 https://doi.org/10.1016/j.postharvbio.2015.05.017

FAOSTAT (2018). Food and Agriculture Organization of the United Nations. Retrieved in June, 10 , 2018 from http://www.fao.org/faostat/en/\#data/QC

Geeson J D, Browne K M \& Guaraldi F (1986). The effects of ethylene concentration in controlled atmosphere storage of tomatoes. Annals of Applied Biology 108(3): 605-610 https://doi.org/10.1111/j.1744-7348.1986.tb01999.x

Guilen F, Castillo S, Zapata P J, Martinez-Romero D, Serrano M \& Valero D (2007). Efficacy of 1-MCP treatment in tomato fruit 1. Duration and concentration of 1-MCP treatment to gain an effective delay of postharvest ripening. Postharvest Biology and Technology 43(1): 2327 https://doi.org/10.1016/j.postharvbio.2006.07.004

Gonzalez-Aguilar G A, Ayala-Zavala J F, De la Rosa L A \& Alvarez-Parrilla E (2010). Fruit and vegetable phytochemicals: Chemistry, nutritional value and stability. Wiley-Blackwell, Oxford

Jan I \& Rab A (2012). Influence of storage duration on physico-chemical changes in fruit of apple cultivars. The Journal of Animal \& Plant Sciences 22(3): 708-714

Kapotis G, Passam H C, Akoumianakis K \& Olympios C M (2004). Storage of tomatoes in low oxygen atmospheres inhibits ethylene action and polygalacturonase activity. Russian Journal of Plant Physiology 51(1): 112-115 https://doi.org/10.1023/B:RUPP.0000011310.84965.74

Karacali I (1990). Storage and marketing of horticultural products. Ege University, Faculty of Agriculture, Bornova/İzmir (In Turkish)

Maharaj R, Arul J \& Nadeau P (1999). Effect of photochemical treatment in the preservation of fresh tomato (Lycopersicon esculentum cv. Capello) by delaying senescence. Postharvest Biology and Technology 15(1): 13-23 https://doi.org/10.1016/S0925-5214(98)00064-7

Mcguire R G (1992). Reporting of objective colour measurements. HortScience 27(12): 1254-1255 https://doi.org/10.21273/HORTSCI.27.12.1254

Mohammed M, Wilson L A \& Gomes P I (1999). Postharvest sensory and physiochemical attributes of processing and non-processing tomato cultivars. Journal of Food Quality 22(2): 167-182 https://doi.org/10.1111/j.1745-4557.1999.tb00549.x

Nagata M, Mori H, Tabei Y, Sato T, Hirai M \& Imaseki H (1995). Modification of tomato fruit ripening by transformation with sense or antisense chimeric 1-aminocyclopropane-1-carboxylate synthase genes. Acta Horticulturae 394: 213-218 https://doi.org/10.17660/ActaHortic.1995.394.22

Nyalala S P O \& Wainwright H (1998). The shelf life of tomato cultivars at different storage temperatures. Tropical Science 38: 151-154

Prasanna V, Prabha T N \& Tharanathan R N (2007). Fruit ripening phenomena-An overview. Critical Reviews in Food Science and Nutrition 47(1): 1-19 https://doi.org/10.1080/10408390600976841

Sammi S \& Masud T (2007). Effect of different packaging systems on storage life and quality of tomato (Lycopersicon esculentum var. Rio grande) during different ripening stages. Internet Journal of Food Safety 9: 37-44

Tigist M, Workneh T S \& Woldetsadik K (2013). Effects of variety on the quality of tomato stored under ambient conditions. Journal of Food Science and Technology 50(3): 477-486 https://doi.org/10.1007/s13197-011-0378-0

Wills R, Mcglasson B, Graham D \& Joyce D (1998). An introduction to the physiology and handling of fruit, vegetables and ornamentals. UNSW press, New South Wales

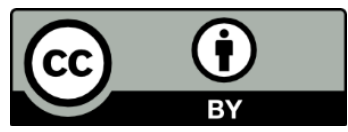

(C) 2021 by the authors. Licensee Ankara University, Faculty of Agriculture, Ankara, Turkey. This article is an open access article distributed under the terms and conditions of the Creative Commons Attribution (CC BY) license (http://creativecommons.org/licenses/by/4.0/). 